\title{
層理面のひすみ軟化挙動に起因する流れ盤斜面の地震時崩壊 の有限要素シミュレーション

\author{
Finite element simulation for collapse of dip slope during earthquake \\ induced by strain-softening behavior of bedding plane
}

\author{
若井明彦 $^{\mathrm{a})} \cdot$ 鵜飼恵三 ${ }^{\mathrm{a})} \cdot$ 尾上篤生 $^{\mathrm{b})} \cdot$ 樋口邦弘 $^{\mathrm{c})} \cdot$ 黑田清一郎 ${ }^{\mathrm{d})}$ \\ Akihiko WAKAI, Keizo UGAI, Atsuo ONOUE, Kunihiro HIGUCHI and Seiichiro KURODA
}

\begin{abstract}
Many landslides in mountain area occurred during 2004 Mid Niigata Prefecture Earthquake in Japan. Numerical simulation for the collapse of a dip slope by the 2-D dynamic elasto-plastic finite element method is reported. To simulate such a catastrophic failure, the strain-softening characteristics under cyclic loading for the thin sand seam within the bedding plane were investigated, based on the cyclic direct shear tests of undisturbed block samples. As a result, the observed phenomena could be simulated well by the analysis and it was suggested that a long distance traveling failure was induced by the strain-softening behavior of the bedding plane.

Key words : dip slope, collapse, bedding plane, strain-softening, finite element method

\section{和文要旨}

2004年の新潟県中越地震では中山間地における多数の斜面崩壊が発生した。二次元動的弾塑性有限要素法によりある流れ盤斜面 の崩壊を再現した事例を報告する。このような大規模崩壊を再現するために，不擋乱ブロック試料による繰返し直接せん断試験に 基づいて，層理面に介在する薄い砂層の繰返し載荷時のひずみ軟化特性が検討された。その結果，観測された現象が精度良く再現 され，長距離移動型の崩壊が層理面のひずみ軟化挙動により誘引されることが示唆された。

キーワード : 流れ盤斜面, 崩壞, 層理面, ひずみ軟化, 有限要素法
\end{abstract}

\section{1. はじめに}

2004年の新潟県中越地震（M6.8）では，震源に近い 川口町や山古志村 (当時)，堀之内町 (当時)，長岡市の 一部などを中心に広範かつ多数の斜面崩壊が発生した。 このような中山間地における同時多発的な土砂災害の被 害を軽減するための広域的あるいは個別事象的検討はそ れぞれ始められたばかりである。本研究では，これら多 様な斜面崩壊の中で，流れ盤斜面が地震時に大規模崩壊 する現象に着目し，その主たる誘因と考えられる層理面 の力学特性をモデル化するとともに，斜面崩壊を数值解 析的に再現することを試みた。

動的弾塑性有限要素法（FEM）による地震時の斜面 の安定性評価の試みは以前から数多くある(例えば, Toki et al. (1985), Griffiths et al. (1988), Woodward et al. (1994), Ugai et al. (1996), Iai et al. (1999), Uzuoka (2000)，浅野他（2006）など)。解析に用いる 弾塑性構成モデルの性質により，得られる結果の特徴は さまざまであるが，対象とする斜面を構成する土の力学 特性を適切に表現できる弾塑性構成モデルを用いないと, 精度良い予測結果は得られない。しかし力学特性を厳密

* 連絡著者/corresponding author

a) 群馬大学

Gunma University

T $376-8515$ 桐生市天神町 $1-5-1$

1-5-1, Tenjin, Kiryu, Gunma 376-8515

b) 長岡工業高等専門学校

Nagaoka National College of Technology

) 侏黑岩測量設計事務所

Kuroiwa Survey and Design Office Co. Ltd

d）独農業・食品産業技術総合研究機構農村工学研究所

National Institute for Rural Engineering
に再現できるモデルの構築を追求するほど定式化は複雑 になり，モデルを記述するパラメー夕の数も多くなる。 厳密に液状化地盤の挙動を再現するような場合は別とし て，一般の斜面の耐震設計への適用を考える場合，現象 予測に必要な精度を有しつつも出来るだけ単純な構成モ デルが便利である。

この点に着目して, Wakai and Ugai（2004）は土の 動的変形特性（いわゆる $\mathrm{G}-\gamma, \mathrm{h}-\gamma$ 関係）とせ几断強 度 $(\mathrm{c} ， \phi)$ をともに考慮しうる簡易な繰返し載荷構成 モデルを提案している。現在しばしば用いられる弾完全 塑性モデルでは応力ひずみ関係がバイリニアとなるため, 現実の地盤の地震応答特性を必ずしも適切に再現してい るとは言えない。上記モデルでは，より現実の土の力学 特性に近い双曲線型の応力ひずみ関係を骨格曲線として 採用し, さらに修正HDモデル等で指摘される過大な減 衰率の問題を解決するために独自の履歴ループ曲線を併 用した。これにより実際の土に近い適切な動的変形特性 を表現するとともに，Mohr-Coulomb規準に基づいて地 盤のせん断破壊を精度良く再現することができる。

土木分野では性能照査型の耐震設計手法の開発が求め られる中，液状化解析への拡張（若井他 (2003)), 土の 不均質性の影響（若井他 (2005a)), 中山間地広域震度 予測（若井他 (2006a)), 補強土擁壁の耐震性（若井他 (2006b)), 宅地盛土の耐震性（若井他（2006c））など, 斜面や土構造物などの地震時挙動に関する種々の実務的 な検討が上記モデルおよびその拡張モデルにより進めら 
れてきた。一方，従来の震度法に基づく極限平衡法では， 地震動の増幅特性などを適切に表現できないばかりでな く，斜面崩壊の有無を安全率でしか議論することができ ないため, 地震後に生ずる有限な変形量を予測すること が困難であった。FEMに基づく地震応答解析により斜 面の残留変形に着目した検討が容易となり，現実の斜面 被害を直接再現しょうとする機運が高まっている。

\section{2. 解析対象とした流れ盤斜面の崩壊例}

\section{1 地震による斜面崩壊の定義}

解析対象とする流れ盤斜面の事例紹介をする前に, こ の崩壊現象を解釈する上で重要となる力学的視点につい て簡単に確認しておきたい。

従来, 斜面崩壊と言うと, 斜面内にすべり面が形成さ れ，斜面内の土塊自重を支えるだけのせん断強度が発揮 されないため，土塊が滑り落ちることを想定する場合が 多い。極限平衡法で安定計算をした時の安全率1.0がこ の限界状態に相当する。

一方，地震による自然斜面の被害を考えると，これら はさらに次の二種類に分けられるべきである。すなわち, (1) 一時的に斜面内に破壊が生じたが, 斜面の残留変位 が限られた大きさで収束した場合

(2) 移動を阻害する地形に衝突するなど，すべり土塊が 元の位置から大きく移動するまで停止しなかった場合

(1) (2) もに極限平衡法で考えるところの安全率1.0を 地震中に下回ったケースであり広義には崩壊と言えるが, (1)を変状，(2)を（狭義の）崩壊と呼んだ方がより適当と 思われる。安全率が1.0を下回ると判定されても, 部分 的変形が認められるのか, 崩壊土砂が長距離移動し河道 閉塞を起こすのかでは, まったく被害規模が異なるので, (1)と(2)を判別するための方法が望まれる。

一方, 従来型のFEMでは, (1)のようにある一定の変 形を再現することはできても，どこまでも停止しない(2) のような力学状態を時刻歴応答解析で追跡することは困 難とされてきた。本研究では，この困難を克服するため，

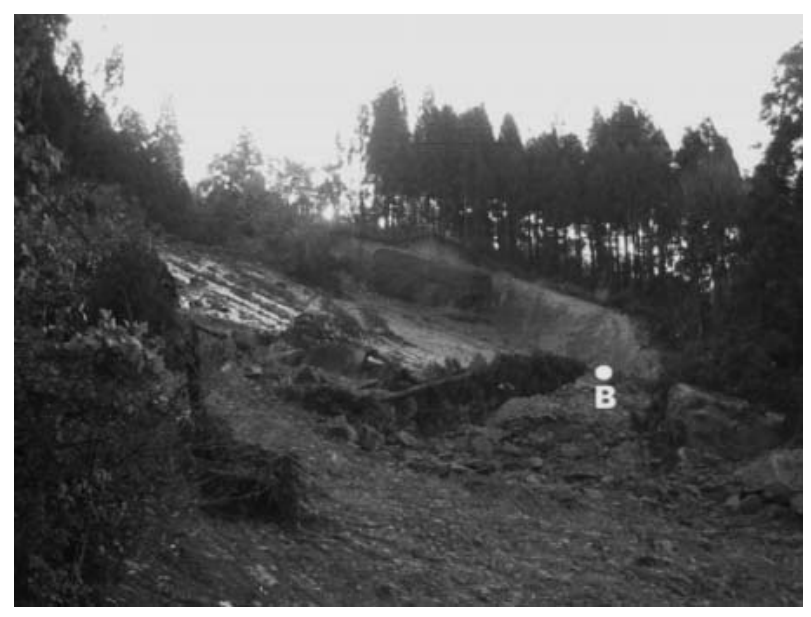

写真一 1 小千谷市横渡の斜面崩壊 Photo 1 Yokowatashi landslide in Ojiya
構成モデル（Wakai and Ugai (2004))に改良を加え， 地震中にすべり面上のせん断強度を低下してすべり土塊 の自重を支えきれなくなった場合には，地震終了後もす ベり土塊の運動が継続するようなモデル化を実現した。

\section{2 小千谷市横渡の斜面崩壊（新潟県中越地震）}

信濃川沿いには白岩層を始めとする新第三系とより新 しい第四紀更新世初期までに堆積した魚沼層が丘陵地や 段丘崖をなして分布している。これらの地層は褶曲し， 背斜軸や向斜軸がほぼ南北方向に伸びている。小千谷市 付近の信濃川沿いは背斜軸の西側に当たり，西側に傾斜 する地層構造となっていることから, 小千谷市横渡から 長岡市白岩・妙見町にかけては，信濃川とほほ平行する 北一南の走向を示す白岩層が信濃川に向かって $20^{\circ}$ 前後 で傾斜するいわゆる流れ盤構造をなしている。

この地域で明瞭なすべり面が認められた国道291号線 東側の斜面崩壊（写真－1）を本研究の検討対象とする。 この事例は平らな層理面をすべり面とする地すべり性の 崩壊である。すべり面上の土塊は信濃川に向かって西側 へ70mあまり移動している（写真－2）。新潟県中越地 震では本震直後の短時間に複数回の強い余震が発生して いることから，このすべり土塊は本震もしくはいずれか の余震の最中かその直後に移動したものと考えられるが, 正確な移動時刻は不明である。Onoue他（2006）はこの 崩壊斜面の地質学的特徴の整理, 極限平衡法に基づく力 学的な考察を行っており, 地震動により層理面で破壊が 生ずる可能性について示唆している。

図 - 1 に後述の数值解析で用いる有限要素メッシュと ともに，斜面形状の概要を紹介する。斜面の山側背面に は小さな凹地があり, 崩壊した上部岩盤部分が板状に載 るような地形をしている。同じ国道沿いに隣接する類似 した崩壊斜面の地形・地質構造と合わせて考えると, こ れらは典型的なケスタ地形と見られる。

現地計測によると，すべり面を構成した層理面の西向 き傾斜角度は約 $22^{\circ}$ であった。すべり土塊の厚さは南北

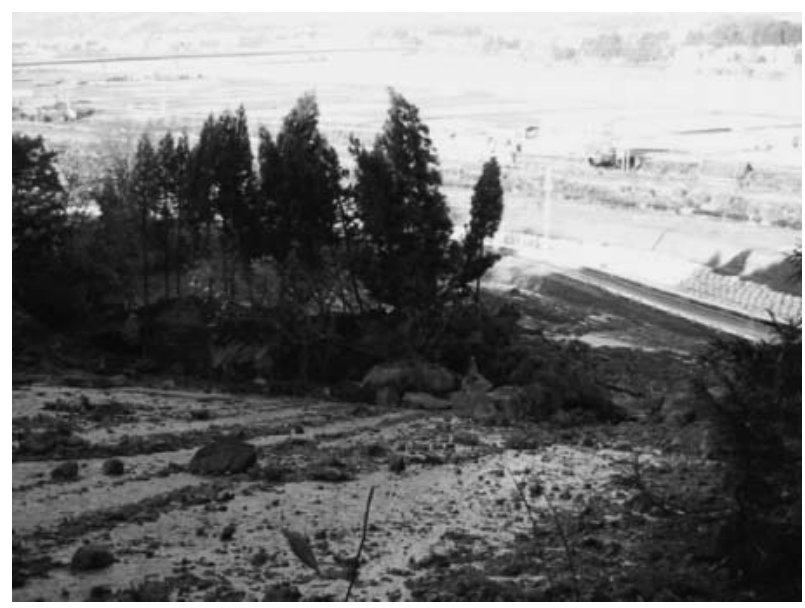

写真一 2 信濃川方向へ移動堆積した土塊 Photo 2 Debris moved toward the Shinano river 


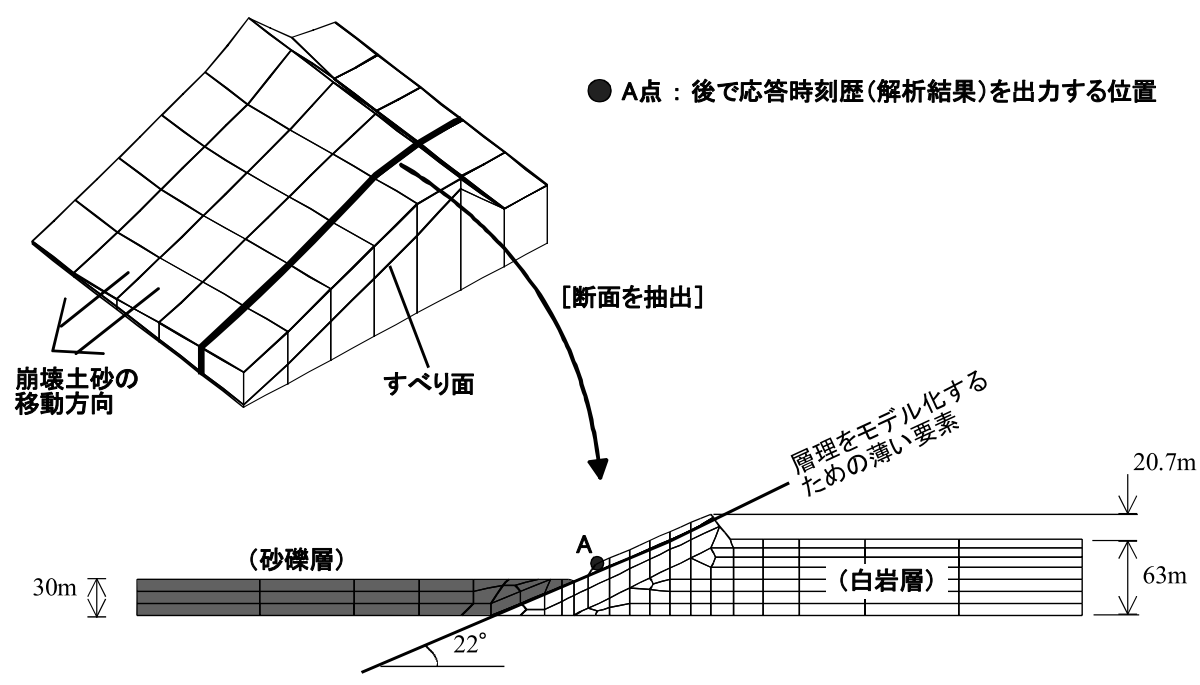

図一 1 解析に用いる二次元有限要素メッシュ

Fig. 1 Two dimensional finite element meshes for simulation

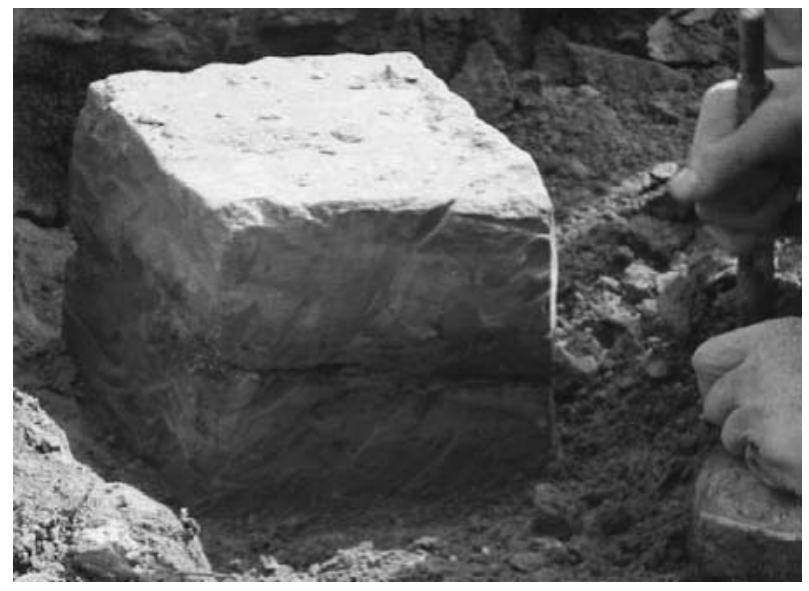

写真ー 3 室内試験のための不営乱ブロック試料 Photo 3 Undisturbed block sample for laboratory tests

方向（土塊移動に対して直角方向）にやや変化しており， すべり土塊の主体である白岩層の厚さは，南縁ですべり 面上約 $4.0 \mathrm{~m}$, 北縁で約 $2.5 \mathrm{~m}$ であった。解析では図 -1 のような中間の二次元断面に着目するため, すべり土塊

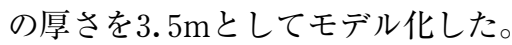

\section{3 層理面の状況とブロック試料の採取}

写真 -1 の右奥の残留露頭下部（写真中のB点）にお いて，上下の白岩層岩塊に層理面が挟在する形のブロッ ク試料を採取した (写真 -3$)$ 。後述のように，この試 料により層理面の力学特性を調べるための室内強度試験 を実施し，解析に用いる地盤パラメータを決定した。

層理面は厚さ $5 \sim 10 \mathrm{~mm}$ 程度の凝灰質砂層で構成され る。解析では $10 \mathrm{~mm}$ 厚の要素でモデル化した。白岩層全 体は灰色であるが，層理面の境界から $80 \mathrm{~mm}$ 程度より近 い部分は風化が顕著であり褐色を呈している。また，こ の風化した変色带は白岩層内部の多くの亀裂に沿って同 様に発達しており，これらを浸透する雨水や地下水に追 随した一部の植物根が侵入した形跡が観察された。ただ
し，本解析では凝灰質砂層におけるすべりを中心にモデ ル化するため，本風化領域はモデル化しなかった。

\section{3. 崩壊を再現するための解析モデル}

\section{1 基礎方程式}

動的弾塑性FEMでは, 以下の運動方程式をNewmark の $\beta$ 法 $(\beta=0.25)$ により時間積分して解く。

$$
[M]\{\ddot{u}\}+[C]\{\dot{u}\}+\{P\}=-[M]\{\ddot{U}\}
$$

$\{P\}$ は内部応力に等価な節点力ベクトルであり, 線形 弾性体では $\{P\}=[K]\{u\}$ である。 $[M],[C],[K]$ はそ れぞれ質量, 減衰, 初期剛性マトリクス, $\{u\},\{U\}$ は それぞれ（各位置の）相対変位，(基盤の）絶対変位べ クトルである。減衰マトリクスの導出にはRayleigh減衰 を仮定した。

$$
[C]=\alpha[M]+\beta[K]
$$

今回は周波数 0.5 および $5.0 \mathrm{~Hz}$ で減衰率 $3 \%$ となる值 として $\alpha=0.171, \beta=0.00174$ を仮定した（Wakai and Ugai (2004))。

\section{2 地震時ひずみ軟化を再現する弾塑性モデル}

後述（図－2）のブロック採取試料による繰返し直接 せん断試験結果から推察されるように，地震中，層理面 に大きなせん断応力が繰返し載荷されたことにより, 急 激に層理面のせん断抵抗が減少し，ついには上部岩盤の 自重を支えきれなくなり，大規模崩壊に至ったと考えら れる。

一般に液状化の再現を目的とした構成モデルでは，負 のダイレイタンシーに伴う過剩間隙水圧上昇が有効拘束 圧の低下をもたらし，結果的にせん断抵抗が失われると いう力学的枠組みでモデルが構築されている（渦岡 （2000）など）。これは土一水連成系の運動方程式に基つ く盛土の有効応力解析を行う際の一般的なモデル化手法 
の一つである。

しかし，今回のように，自然堆積した固結構造の一部 が劣化することに伴い徐々に強度が低下するような場合, 必ずしも間隙水圧の上昇だけがひずみ軟化の主因ではな い。そこで，損傷の累積によりせん断強度が徐々に低下 するひずみ軟化モデルを用いた全応力解析を採用するこ とにした。

冒頭に述べたWakai and Ugai（2004）による構成モ デル（以降，UWモデルと略）を，土のひずみ軟化特性 を再現できるように改良した（以降，UW軟化モデルと 略）。大部分の定式化はUWモデルと同じであるので, 以下には，拡張した部分だけを記述する。

UWモデルでは, 強度定数 $c, \phi$ とMohr-Coulombの破 壊規準式に基づいてせん断強度 $\tau_{f}$ を定義するが, UW軟

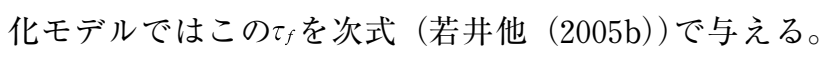

$$
\tau_{f}=\tau_{f 0}+\frac{\tau_{f r}-\tau_{f 0}}{A+\gamma^{p}} \gamma^{p}
$$

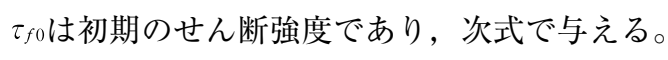

$$
\tau_{f 0}=c \cdot \cos \phi+\left(\frac{\sigma_{1}+\sigma_{3}}{2}\right)_{\text {initial }} \times \sin \phi
$$

$\tau_{f r}$ は残留強度状態でのせん断強度であり，簡単化のた め $\tau_{f 0}$ に対する低減率で与えることにする。Aは無次元の 定数である。 $\gamma^{p}$ は累積塑性せん断ひずみであり, 次式で 与える。

$$
\begin{aligned}
& \gamma^{p}=\int d \gamma_{\max }^{p} \\
& d \gamma_{\max }=\left|d \varepsilon_{1}^{p}-d \varepsilon_{3}^{p}\right|
\end{aligned}
$$

$\tau_{f}$ が低下する程度に比例して初期せん断弾性係数 $G_{0}$ (およびヤング率 $E$ ) が低下すると仮定した。塑性ポテ ンシャルにはvon Mises型の関数を仮定することで，等 体積（非排水）条件を実現した。

以上の構成モデルを層理面材料に適用した。一方，層 理面上下の白岩層はともに線形弾性体, 斜面の谷側に堆 積する砂鿬層はひずみ軟化を生じない通常のUWモデル を適用した。砂鿬層の材料定数を設定する際に目標とす る動的変形特性には一般的な物性（石原（1976））を仮定 した。

\section{3 大変形問題を扱う際の留意点}

通常のFEM解析コードでは微小変形問題としての定 式化, すなわち初期座標の参照とCauchy応力・微小ひ ずみの利用が前提である。一方，大変形を扱う問題では Total Lagrange法など, Jaumann応力速度に着目して Cauchy応力を補正するといった有限変形解析が広く行 われる。本解析では，参照座標系の更新により同様の効 果を考慮できるUpdate Lagrange法を採用した。同手法 の数值計算の安定性は良好であった。

ただし，すべり土塊が高速長距離移動する現象を精度 良く再現するには, 上述の幾何学的非線形の定式化だけ
では不十分であり，運動学的な見地からのモデル化が必 須である。例えば，すべり面のせん断抵抗が室内試験で 言う残留強度状態に至ったというのは，あくまでも静力 学特性を念頭に置いた描写である。静摩擦と動摩擦の議 論から容易に推測されるように，実際の移動土塊に作用 するせん断抵抗や減衰はより小さい可能性がある。そこ で本解析では，地震中のひずみ軟化により層理面の強度 が低下し，上部土塊の自重を支えきれなくなった場合に は, Rayleigh減衰のうち剛性比例成分を強制的に零とし た。今回と材料定数の一部が若干異なるものの, Rayleigh減衰の剛性比例成分を零にしないモデル化に基 づく計算例が，尾上他（2005）により報告されている。 崩壊後の上部土塊の移動速度は今回に比べてかなり小さ い結果となっている。

いずれにせよ今回のようなモデル化では高速移動現象 の再現精度に限界がある。従って, 以降の解析結果を考
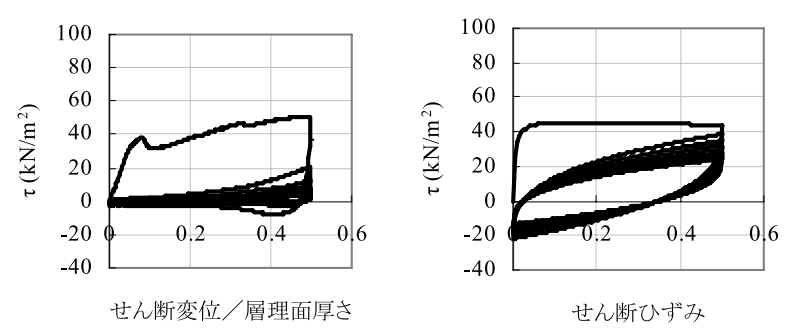

(a) $\sigma=40 \mathrm{kN} / \mathrm{m}^{2}$
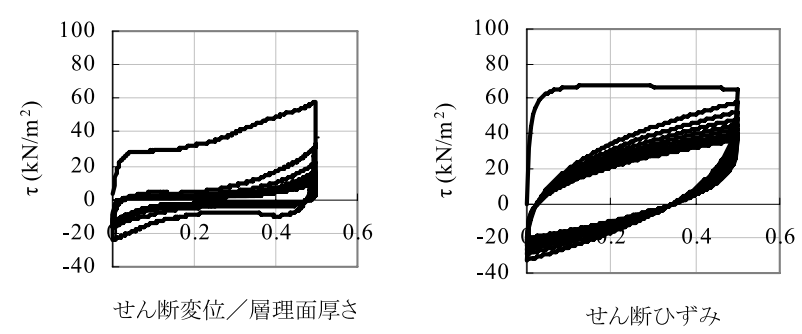

(b) $\sigma=80 \mathrm{kN} / \mathrm{m}^{2}$
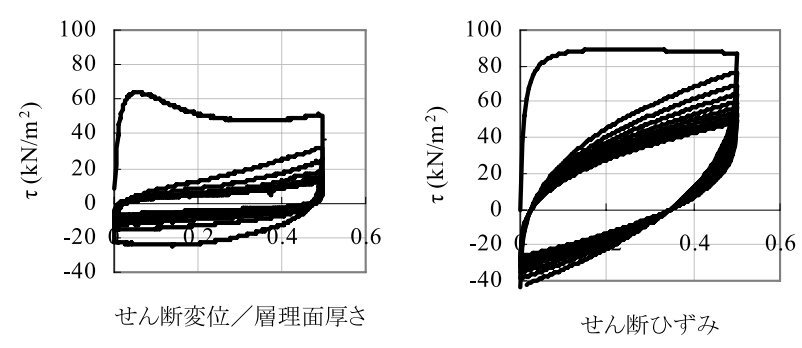

(c) $\sigma=120 \mathrm{kN} / \mathrm{m}^{2}$

$\sigma$ : 初期垂直応力（Initial normal stress）

図-2 層理面の不擋乱試料の繰返し載荷試験（左）とUW 軟化モデルによる再現（右）

Fig. 2 Hysteretic loops observed in cyclic loading tests of undisturbed specimen of bedding plane (left column) and simulation by UW-softening model (right column) 
察する際には，顕著な滑動が開始された後の土塊の加速 状態については特に重視せず，顕著な滑動が開始される かどうかを判別する，という点に焦点を当てて議論を進 めていきたい。この点だけであっても, 従来のFEM解 析で扱うことのできなかった現象を再現する本研究の新 規性であることには変わりがない。4.3節で触れるよう に，高速運動そのものの再現は今後に残された課題であ る。

\section{4. 解析条件と解析結果の考察}

\section{1 地盤パラメータ}

既述のように，層理面にはUW軟化モデル，砂礫層に はUWモデル，白岩層には線形弾性モデルを適用する。 材料定数の一覧を表 -1 に示す。ヤング率 $E$, ポアソン 比ע, 単位体積重量 $は$ はい゙れも一般值（例えば，地盤工 学会編（2003）を参照）を仮定した。なお, 砂緩層や白 岩層の物性值は, 層理面のそれに比べると解析結果への 影響度は小さい。そこで層理面の定数を適切に決定する ため，層理面を挟むブロック採取試料の一部をせん断箱 に収まるように切り出し（写真－4），これを用いて繰 返し載荷ならびに単調載荷の直接せん断試験を実施した (試験は応用地質(侏)コアラボによる)。結果を図 - 2 に示 す。地震時を考慮して，いずれも等体積（非排水）条件 とした。表 -1 における層理面の $c, \phi$ 単調載荷時の ピーク強度の実測值である。その他, 試験結果を再現す るように，試行錯誤的にパラメータ群を決定した。

表ー 1 のパラメータに基づき, 繰返し直接せん断試験 （せん断変位振幅 $5 \mathrm{~mm} /$ 片振り条件）結果を, UW軟化 モデルで再現して比較したものが図 - 2 である。初期拘 束圧 $40,80,120 \mathrm{kN} / \mathrm{m}^{2}$ そぞれの場合について, 試験 と解析の応力ーひずみ履歴を対比した。試験結果の横軸 は変位であるが，これを層理面の厚さ $10 \mathrm{~mm}$ で除して解 析結果と比較できるひずみの次元とした。試験と解析と

表ー 1 解析に用いたパラメータの一覧

Table 1 Analytical parameters used in FEM analysis

\begin{tabular}{|c|c|c|c|c|}
\hline & & 層理面 & 砂礫層 & 白岩層 \\
\hline \multirow{8}{*}{$\begin{array}{l}\text { 基 } \\
\text { 本 } \\
\text { 的 } \\
\text { な } \\
\text { 材 } \\
\text { 料 } \\
\text { 定 } \\
\text { 数 }\end{array}$} & $\begin{array}{l}\text { ヤング率 } \\
E\left(\mathrm{kN} / \mathrm{m}^{2}\right)\end{array}$ & 30000 & 30000 & 100000 \\
\hline & $\begin{array}{c}\text { ポアソン比 } \\
v\end{array}$ & 0.3 & 0.3 & 0.3 \\
\hline & $\begin{array}{l}\text { 粘着力 } \\
c\left(\mathrm{kN} / \mathrm{m}^{2}\right)\end{array}$ & 24 & 0 & - \\
\hline & $\begin{array}{c}\text { 内部摩擦角 } \\
\phi(\mathrm{deg})\end{array}$ & 30.9 & 35 & - \\
\hline & $\begin{array}{c}\text { ダイレイタン } \\
\text { シー角 } \\
\psi(\mathrm{deg})\end{array}$ & 0 & 0 & - \\
\hline & $b \cdot \gamma_{G_{0}}$ & 8.0 & 18. & - \\
\hline & $n$ & 1.40 & 1.35 & - \\
\hline & $\begin{array}{c}\text { 単位体積重量 } \\
\gamma\left(\mathrm{kN} / \mathrm{m}^{3}\right)\end{array}$ & 18.0 & 18.0 & 20.0 \\
\hline \multirow{2}{*}{$\begin{array}{l}\text { ひずみ } \\
\text { 軟化 } \\
\text { 定数 }\end{array}$} & $\begin{array}{c}\text { 残留強度比 } \\
\tau_{f \mathrm{r}} / \tau_{f 0}\end{array}$ & 0.30 & - & - \\
\hline & $A$ & 4.0 & - & - \\
\hline
\end{tabular}

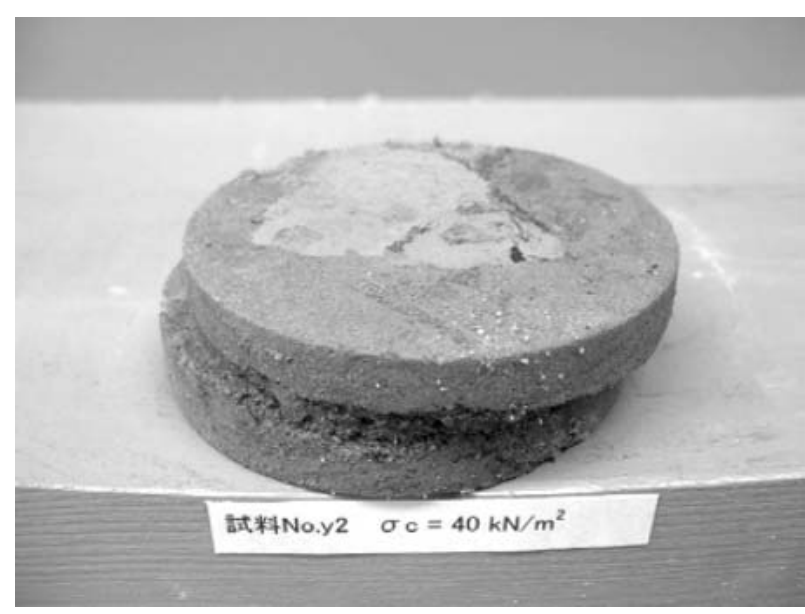

写真－4 試験後の層理面供試体（上下の白岩層に挟まれた シーム状の砂層)。

Photo 4 Tested specimen consisting of upper and lower Shiroiwa layers with sand seam in between

は完全には一致していないが，拘束圧とともに増大する せん断抵抗，繰返し載荷の第二回目ループから見かけの 強度が急激に低下する特徵，などをいずれも良く表現し ている。

\section{2 外力等の条件}

地震動を入力した時刻歴応答解析の前に自重による初 期応力状態を実現するため, 解析過程の第一段階では, せん断強度低減法に基づく自重つり合い計算を行った。

時刻歴応答解析では，新潟県中越地震の時に山古志村 （当時）竹沢で観測された強震記録 $(\mathrm{EW})($ 図 - 3 ) を 有限要素メッシュの下端に入射する水平加速度として用 いた。なお，地震外力については不確定要素が極めて多 い。これらの不確定要素について以下に例を挙げる。

- 竹沢の観測地点より今回の斜面現場 (横渡) の方が 震源に近いことによる距離減衰的な効果

- 竹沢との地形・地質的な相違がもたらす効果

- 観測地震動と今回の斜面方向の相違

・鉛直動を無視した影響

・ 本震あるいは何番目の余震が崩壊の主因なのか

・間隙水圧の影響

これら個々の事項の精査は極めて困難であるため，今回 はいずれも無視した単純な外力条件で検討を進めた。解

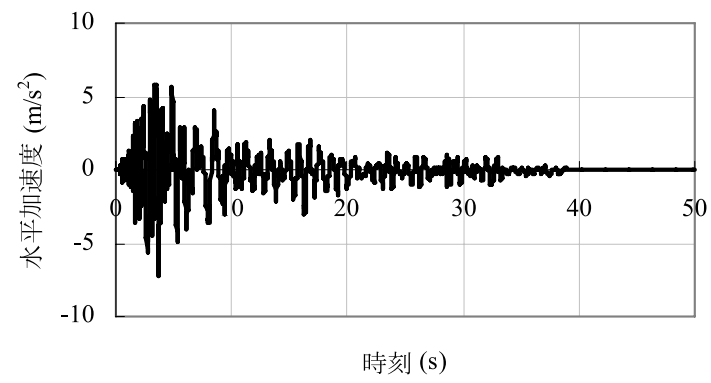

図一 3 FEMにおける入力地震動

Fig. 3 Input earthquake in FEM analysis 
析領域の下端は固定条件，左右側端は水平固定・鉛直方 向の自由変位を許す境界条件とした。

比較のため, 竹沢の観測地震動をそのまま入力した ケース（Full）と振幅を半分にしたケース（Half）をそ れぞれ解析した。今回の地震により崩壊が生じたのだと すれば，逆に言うと，過去の地震では崩壊しなかったと いうことになる。上記二ケースを実施することにより， 今回の解析がこのような事実と矛盾しないかを確認する。

\section{3 解析結果}

二つのケースで得られた図 -1 中の $\mathrm{A}$ 点の水平加速度 を図-4に示す。いずれの場合も基盤に対して $2 \sim 3$ 倍 程度の加速度の増幅が見られる。Fullのケースで時刻歴 後半部に入力動に見られない加速度の増幅が見られるの は，次の変位時刻歴を見るとわかるように，上部土塊が 高速かつ長距離のすべり運動を開始したためである。

次に, 同様にA点における水平変位の時刻歴を図 - 5 に示す。FullのケースとHalfのケースを同じ図中にプ ロットした。ただし，Fullのケースで大きな速度が生じ た時刻歴後半についての運動を示すために, 縦軸のス ケールを変えた図を併記した。入力が竹沢波形の半分の 場合（Half）は残留変位がある一定值にとどまるのに対 して，竹沢波形をそのまま入力する（Full）と大規模崩 壊が生じることが分かる。Fullのケースでは，地震動が 完全に終息した40秒よりあとも継続的に変位が増加する。

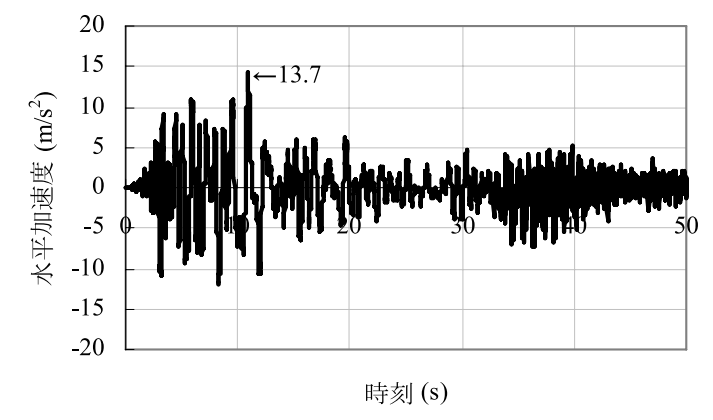

(a) Full case

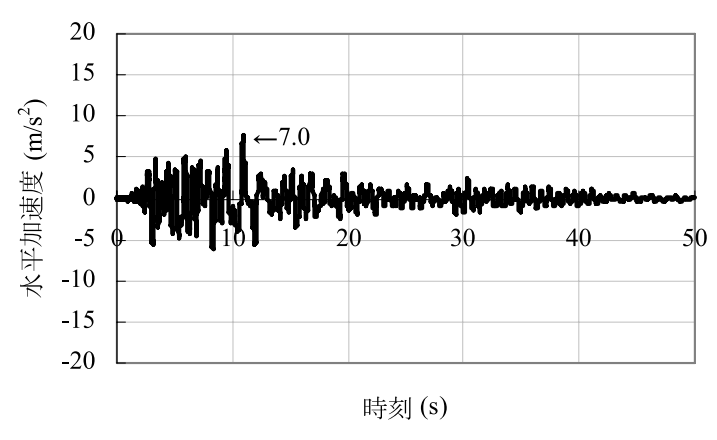

(b) Half case

図一４部白岩層の水平加速度の時刻歴（A点）

Fig. 4 Time history of horizontal acceleration of upper Shiroiwa layer (at Point A)
すべり土塊の移動開始時刻は，地震動の収まりかけた 30秒過ぎであるが，この定量的妥当性については慎重な 議論が望まれる。先に述べた外力条件の不確実性だけで なく, 種々のモデル化上の不確実性がこの移動開始時刻 に大きな影響を与える。例えば，斜面全体の三次元形状 がもたらす複雑な振動（本来は南北にもせん断を受けて いる), 層理面が平面でなく微妙な凹凸が存在するため に生ずる見かけの抵抗効果, 先行降雨がもたらした若干 の水圧の被圧効果, その他経験則に基づいて決定した地 盤パラメー夕の信頼性などがそれぞれ結果に影響を与え ると考えられる。仮定や条件を変えることにより，移動 開始時刻が早まったり，あるいは一度の地震動入力では 崩壞しない結果（実際に経験された複数回の余震により 崩壊に導かれた）を与える場合もあると予想される。こ れらについては不明な点が多いので，移動開始時刻に関 してはこれ以上の議論を進めない。

参考までに, 長距離移動中の運動状態について若干の 考察を行う。既述のように, 今回は厳密な運動学的モデ ル化をしていないため, 運動中の減衰抵抗を過大に評価
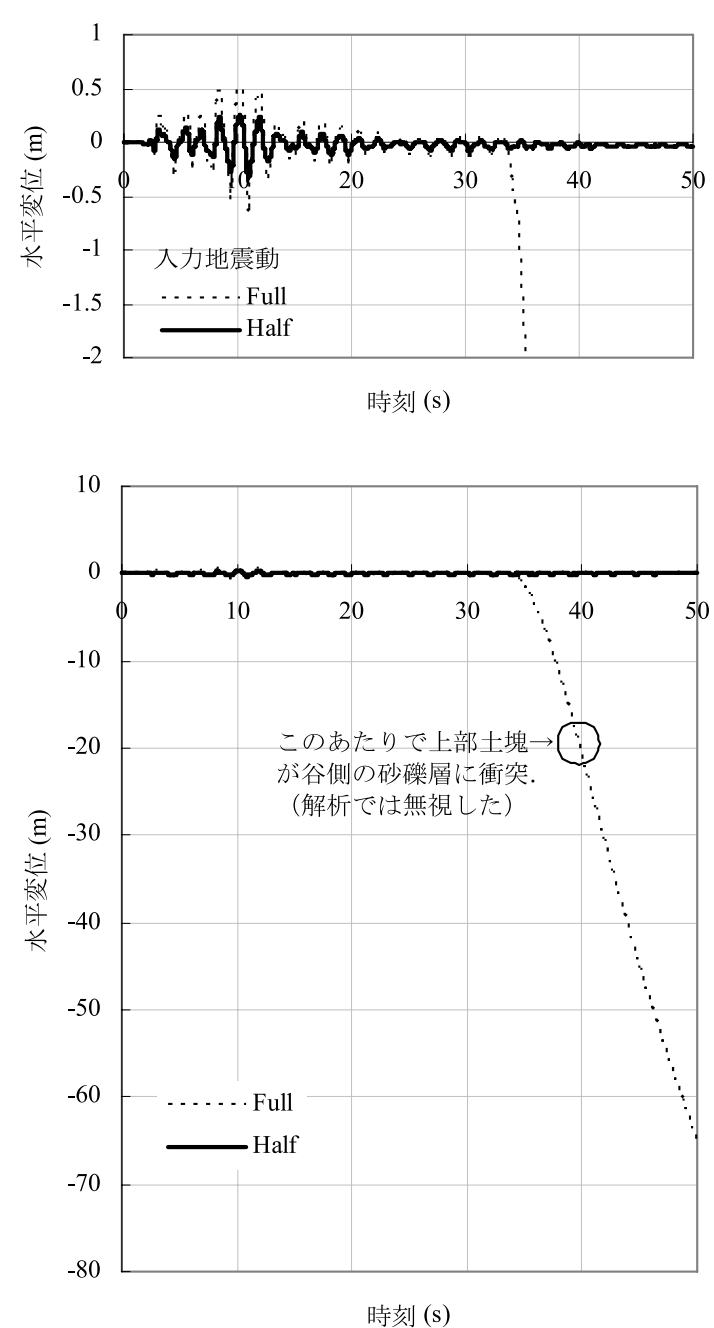

図一 5 上部白岩層の水平変位の時刻歴（A点）

Fig. 5 Time history of horizontal displacement of upper Shiroiwa layer (at Point A) 


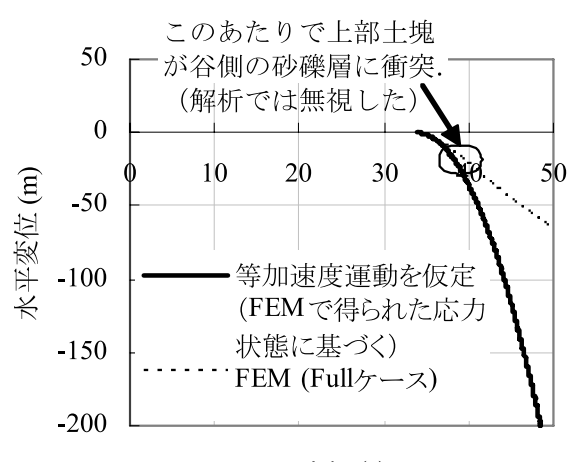

時刻 (s)

図ー6 等加速度運動を仮定したケースとの比較

Fig. 6 Comparison with constant acceleration case

している可能性がある。図－6に示したのは，すべり土 塊の重力の滑動方向成分の大きさからFEM（Fullケー ス）により得られた層理面上のせん断応力（残留強度状 態）の合計值を差し引いた正味の滑動力をもとに，すべ り土塊の滑動加速度を算出し，この加速度が一定に作用 し続けた場合を想定した運動時刻歴を，FEM解析結果 (Fullケース) と比較したものである。FEMの結果では 終末速度以上の加速を生じないため, 等加速度運動の仮 定より小さめな速度を与えることがわかる。1963年にバ イオントダム（イタリア）で発生した造波災害などに見 られるように，すべり土塊が湖に突入した時の段波を予 測することは重要であり, このための数值解析の試みも 行われている（吉松他 (2006))。土塊が湖面に突入する 時の速度は段波の規模を左右する重要な要因であるが, 図－6に示すように，移動距離が長くなればなるほど, 運動中の力学モデルの仮定により異なった予測結果が導 かれる。このような数值解析結果に基づいて段波解析を 行う場合, 防災上の視点から適切な工学的判断が必要で あろう。

以上はA点の応答時刻歴に着目した議論であったが, 再度これを系全体の変形として視覚的に確認したい。地 震中の変形性状を有限要素メッシュの変形として描画し たものが図 -7 である。地震動の後半 30 秒過ぎから層理 面に沿って不連続的なすべり変位が生じ，やがて上部土 塊が谷側へ崩落する様子が再現されている。最終状態で はすべり土塊が谷側の砂磁層に貫入しているように見え るが，今回のFEM解析ではこれらの間の接触判定を省 略しているので, 土塊の運動が谷側の地形に関係なく継 続されている。現実には衝突, 堆積, 停止という現象経 過をたどる。

\section{4 崩壊機構に関する力学的考察}

崩壊機構に関して詳しく考察するため, 層理面上に発 揮されるせん断応力などをもとに結果を再検討する。図 - 8 は層理面のせん断応力ーせん断ひずみ（平均值）関 係である。層理面を構成するすべての要素におけるすべ り方向のせん断応力とせん断ひずみについて, 要素寸法 で重み付けして平均值を算出したものである。Fullの
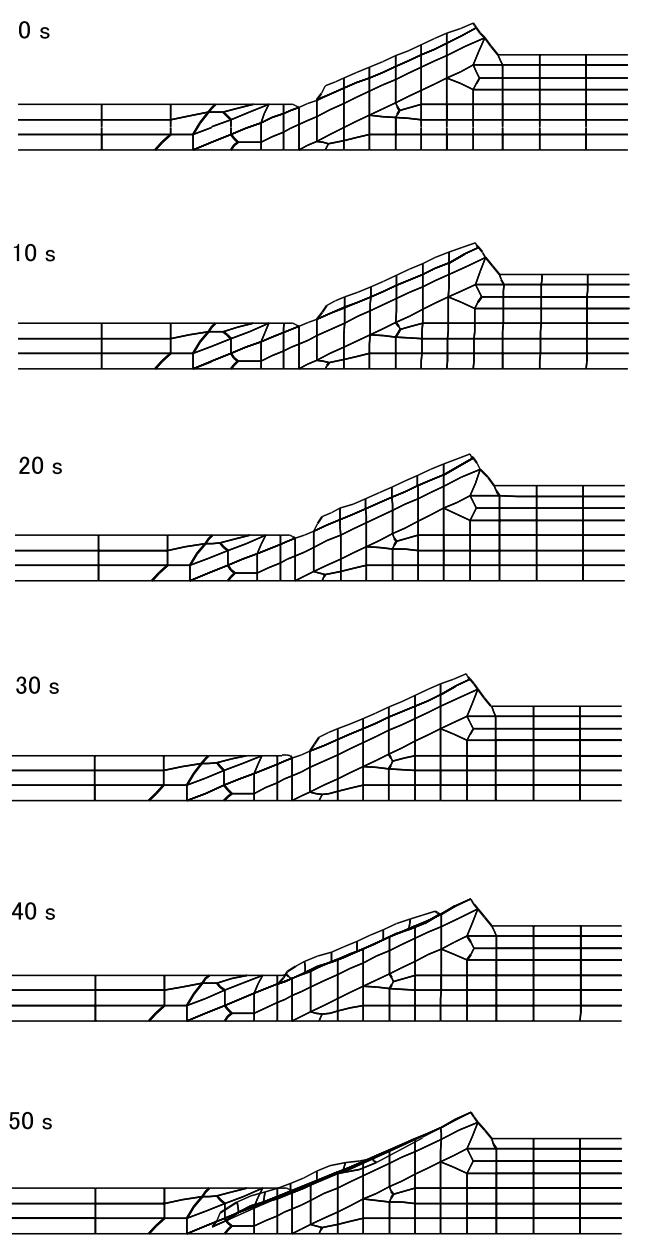

図－７地震中の層理面上のすべり土塊の移動状況

Fig. 7 Movement of the sliding mass on the bedding plane during earthquake

ケース, Halfのケースともに初期応力点は同一であるが, 地震とともに両ケースのひずみの増加度に差が生じ, Fullのケースではせん断応力の低下が継続的に進行する のに対して, Halfのケースでは $45 \mathrm{kN} / \mathrm{m}^{2}$ 程度以下には低 下していない。また, 崩壊を生じたFullのケースでは衝 突を無視した結果，ひずみは増大し続けるのに対して， Halfのケースではある有限な值に収束している。

これを2.1節で述べた(1)変状と(2)崩壊という視点でと らえると，Fullケースが(2)，Halfケースが(1)にそれぞれ 相当する。以上の結果より，過剰間隙水圧や加速度によ り一時的にすべり面が塑性化して強度低下したとしても, すべり面のせん断抵抗力の合計值が上部土塊の自重に起 因する滑動力を下回らないうちは, 地震が終われば土塊 の運動は停止して残留変位は有限值に収束する可能性が あるということである。

一方, 地震中の繰返し載荷によりすべり面の強度が 徐々に低下し, 抵抗力の合計值が上部土塊の静的な自重 を支えられないほどにまで小さくなると, 地震終了後も 上部土塊のすべり運動は停止することなく，移動を阻害 する地形に衝突するか，何らかの要因ですべり面の強度 が回復するまで残留変位は無限に増加し続けることにな 


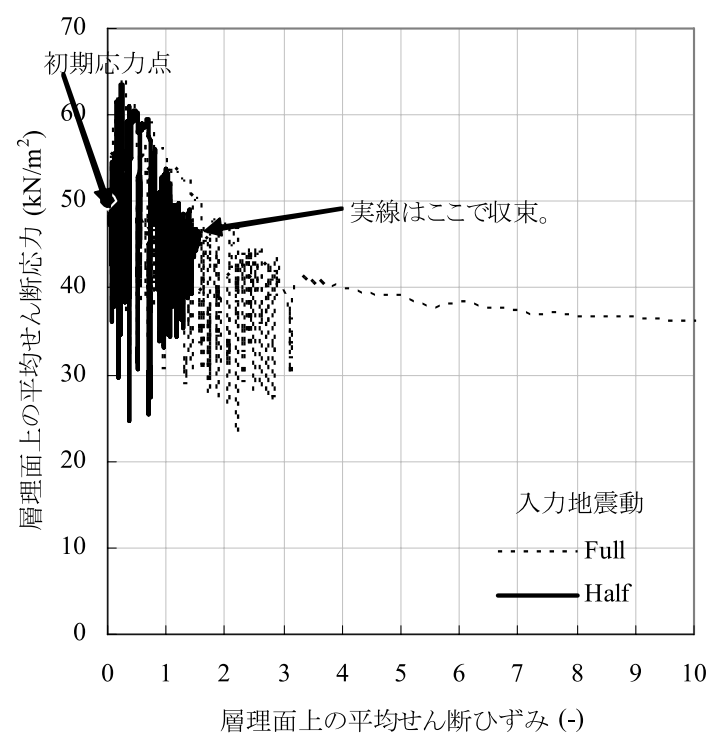

図一8 層理面のせん断応力ーせん断ひずみ関係の履歴

Fig. 8 History of the relationship between shear stress and shear strain of the bedding plane during earthquake

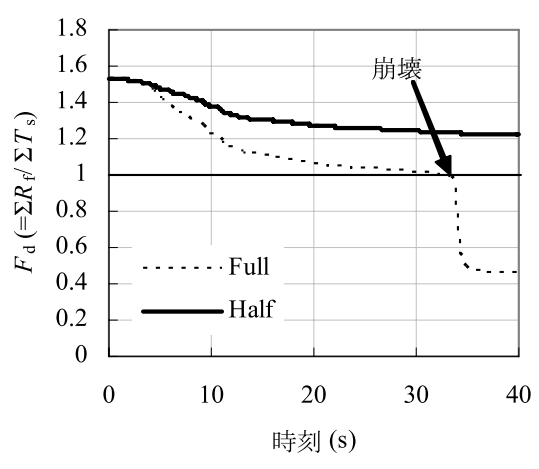

図一 9 提案する安定性指標 $F_{d}$ の時刻歴

Fig. 9 Time histories of the proposed index $F_{d}$

る。これら二種類の結果が大きく異なる理由をより定量 的に議論するための指標を定義したい。

FEM解析から得られた層理面上にせん断応力分布を 検討する際，下式で定義される安定性指標を考える。こ の值が 1.0 を下回る時, 斜面は地震により崩壊すると考 えられる。

$$
F_{d}=\frac{\sum R_{f}}{\sum T_{s}}
$$

ここに,

$\sum T_{s}$ : すべり土塊の自重に起因するすべり面上の滑動 力

$\sum R_{f}$ : すべり面上で発揮されうる最大のせん断抵抗力 である。今回の解析の場合, $\sum R_{f}$ は式(3)で与えられる 各要素のせん断強度 $\tau_{f}$ のすべり面上の総和と等しく, 繰 返し載荷とともに，徐々に低下する量である。一方， $\sum T_{s}$ は自重に基づいて求められる一定值である。震度 法に基づく安全率と異なり, 地震中の慣性力等を $\sum T_{s}$ 中には含めないことに注意されたい。本事例ではすべり
面方向がほぼ一定であるが，非平面すべりであってもす べり面に沿って局所的な $R_{f} と T_{s}$ の值を経路積分すれば 同様に $F_{d}$ が定義できる。

すでに結果を紹介した 2 ケース（Full,Half）それぞれ について，Fr $F_{d}$ 縦軸にとり，この変化を時刻歴として 図示したものが図 - 9 である。 $F_{d}$ が1.0を下回った瞬間, 層理面上の土塊の自重滑動力を抑止するのに必要なだけ のせん断抵抗が層理面上で発揮されなくなることにより, 継続的な滑動が開始する。

図－10は層理面に実際に作用しているせん断応力の総 和 $\sum T （ \sum T_{s}$ ではないことに注意）と $\sum R_{f}$ の時刻歴変 化を示したものである。崩壊するしないにかかわらず， 地震中にすべり面材料自身の内部せん断応力の総和 $\sum T$ が$\sum R_{f}$ を超過することはない。正確に言えば， $\sum T$ が$\sum R_{f}$ を超過しょうとした時に塑性変形が生じ, それによる瞬間的変位（加速度）の大きさに応じた慣性 力や減衰力が, $\sum T$ の超過分を相殺するように生じる ため, 系の力学的平衡 (式 (1)) は常に満足される。Half ケースでは常に $\sum T$ に比べて $\sum R_{f}$ が十分に大きいのに 対して, Fullケースの時刻歴後半部では, $\sum R_{f}$ の急激な 低下に追随して， $\sum T$ が低下している。

読者の誤解を避けるためにあえて説明するが, 震度法 に基づく極限平衡法で斜面安定を議論する際，“地震中 にすべり面上のせん断応力がせん断強度を超えた”とい う表現を使う場合があるが，この場合の「せん断応力」 は，すべり土塊の自重と地震慣性力のすべり方向分力で あることに注意が必要である。材料力学的に考えると, そもそもそれを超過することのない上限のせん断応力が せん断強度なのであるから, 上記の議論で登場する「せ ん断応力」を, すべり面材料自身の内部せん断応力と理 解するのは誤りである。

最後に, 層理面上の各位置で発揮されるせん断応力 $\tau$ と式(3)で与えられるせん断強度 $\tau_{f}$ の分布について，地震 中の各時刻（初期状態, 地震開始 5 秒後, 15 秒後, 50 秒 後）における分布図としてそれぞれ示す。なお，これら の図中の横軸には，斜面の谷側末端部を原点とした水平 座標 $x$ （図-11）を用いている。

図-12はFullケースの，図-13はHalfケースの，せん 断応力 $\tau$ とせん断強度 $\tau_{f}$ の分布状況の経時変化である。 地震前の初期状態では, 斜面の山側より谷側により大き なせん断応力が発生していることがわかる。また, Full ケース, Halfケースともに, 地震とともにせん断強度 $\tau_{f}$ は全般的に低下する。すべり面全体の中では特に谷側の 強度低下が先行的である。これは地震中の繰返し載荷に よる塑性領域が斜面の谷側末端部付近から順次進行する ことを示唆している。Halfのケースでは，地震後に斜面 の山側部分のせん断強度がせん断応力に対してある程度 の余裕を有しており，全体としてすべり土塊の自重を支 えるだけの抵抗力を残存させている。一方, Fullのケー スでは，すべり面全域にわたって強度低下が著しく，表 


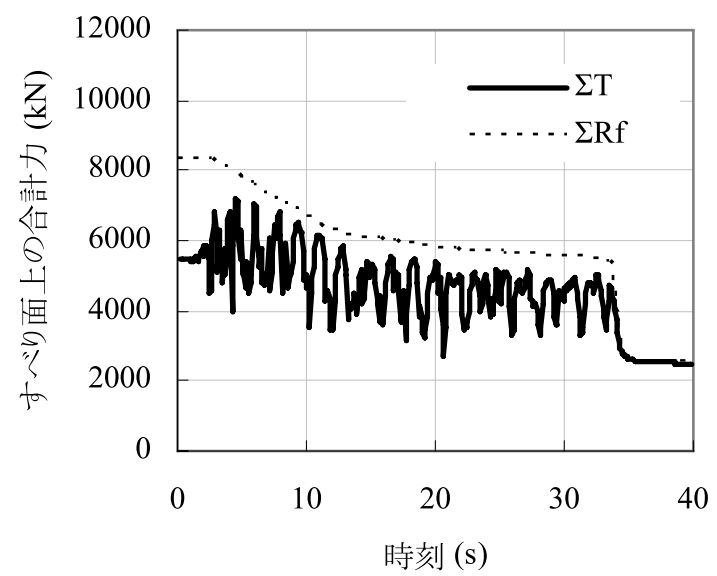

(a) Full case

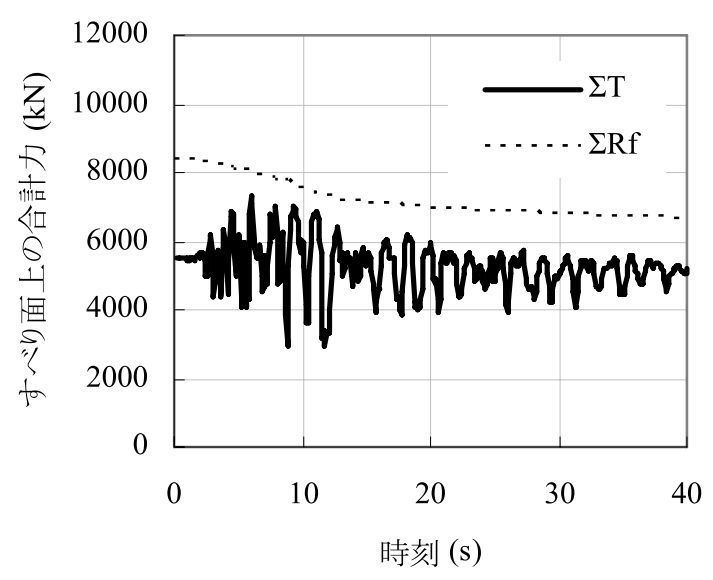

(a) Half case

図一10 せん断応力の総和 $\sum T$ と $\sum R_{f}$ の時刻歴

Fig.10 Time histories of $\sum T$ and $\sum R_{f}$

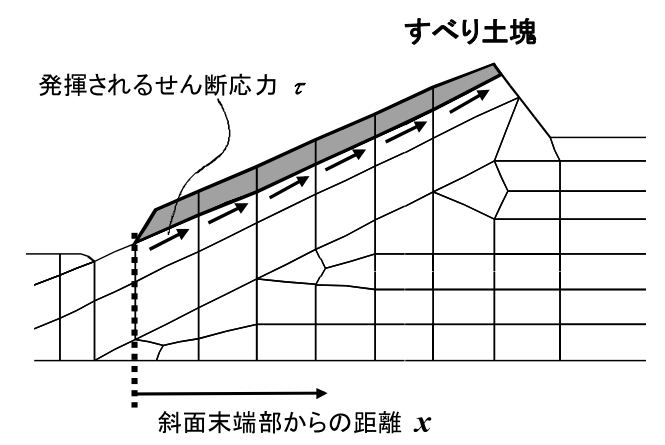

図一11 図一12，13で用いられる座標 $x$ の定義

Fig. 11 Definition of $x$ used in Figures 12 and 13

- 1 で仮定した残留強度に至っている。この結果，斜面 が崩壊に至ったと考えられる。これらの結果は図－9に 基づく地震時斜面崩壊の考え方の妥当性を裏付けている。

\section{5 地下水位を考慮した解析への拡張}

今回提案したFEM解析手法をもとに一般の地すべり 地の地震時安定性を議論する場合, 先行降雨の影響, 地 下水排除工の効果などをふまえた解析をすることが考え

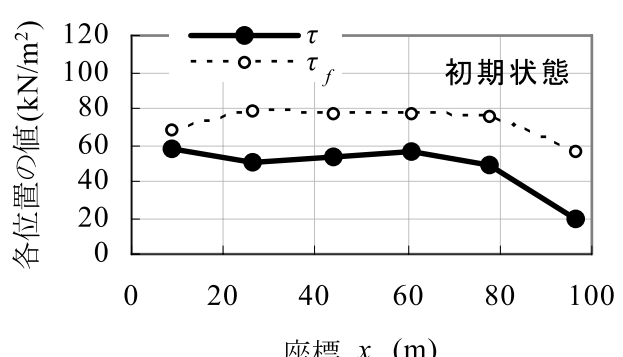

座標 $x(\mathrm{~m})$

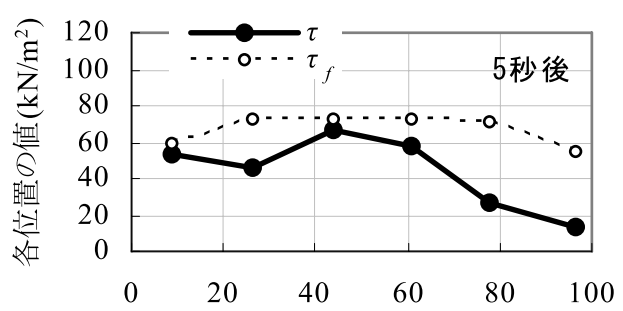

座標 $x(\mathrm{~m})$
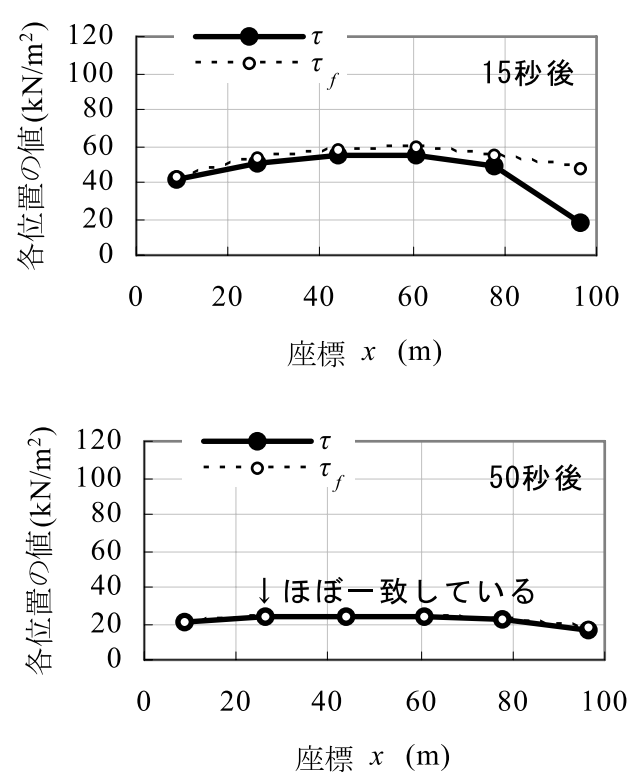

図一12 発揮されるせん断応力 $\tau$ とせん断強度 $\tau_{f}$ の分布（Full ケース)

Fig. 12 Distributions of mobilized shear stress $\tau$ and $\tau_{f}$ (Full case)

られるので，このような解析が可能かどうか，一例を検 討する。

表ー 1 に示した層理面のパラメータのうち, 強度定数 について有効応力規準に読み替えられると仮定すると， 地下水位, 有効拘束圧をもとに初期せん断強度 $\tau_{f 0}$ を得 ることができる。すなわち, 地下水圧があった場合の有 効応力のモール円と破壊線の位置関係が, 地下水圧を無 視した前節までの定式化におけるこれらの関係と同じに なるように破壊線を移動させた結果，得られる強度が初 期せん断強度 $\tau_{f 0}$ である。この $\tau_{f 0}$ に対して，これまでと 同様のひずみ軟化特性を考慮した解析を実施する。ただ し, 地震中は非排水状態と仮定し, 全応力解析を行う。 地下水位以浅は湿潤重量, 以深は飽和重量を用いて慣性 

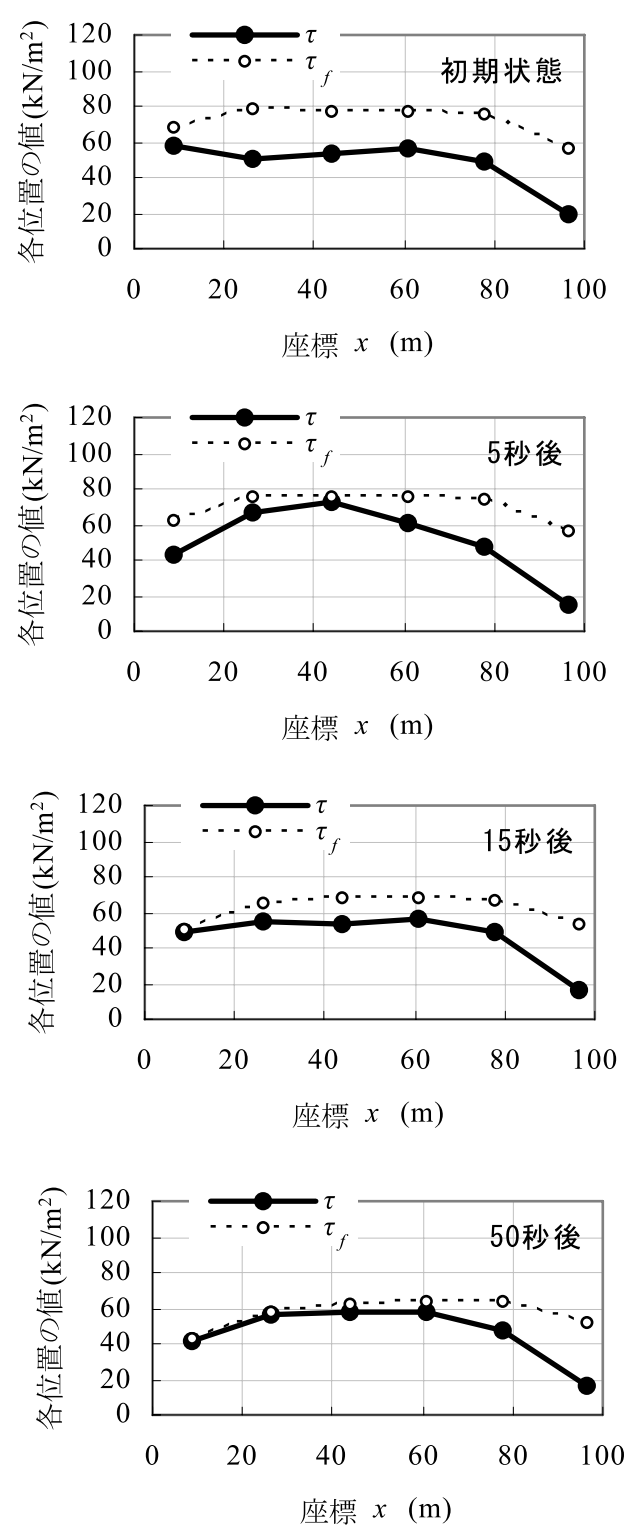

図一13＼cjkstart発揮されるせん断応力 $\tau$ とせん断強度 $\tau_{f}$ の分布（Half ケース)

Fig. 13 Distributions of mobilized shear stress $\tau$ and $\tau_{f}$ (Half case)

力を算定し, 動的応答解析を行う。

図ー14のように，すべり土塊の中間深さに地下水位が 存在している場合を想定した解析の結果を以下に示す。 地震動はFullのケースと同一の波形を用いた。図ー15は これまでの図 -5 と対比すべき $\mathrm{A}$ 点の応答変位, 図-16 は図-9 と対比すべき安定性指標 $F_{d}$ の時刻歴を，それ ぞれ既述のFullケースの結果と一緒に図示したものであ る。Fullのケースの結果に比べて, すべり面上の強度低 下が顕著になり，崩壊する時刻が早まったことが確認で きる。このような解析により，主として豪雨時を想定し た地すべり対策としての地下水排除工の, 地震時安定に 対する有効性が評価できると考えられる。

なお，上記計算例はあくまでも解析手法の拡張の方向 性と解析結果への感度を紹介したものであり, 現実に図

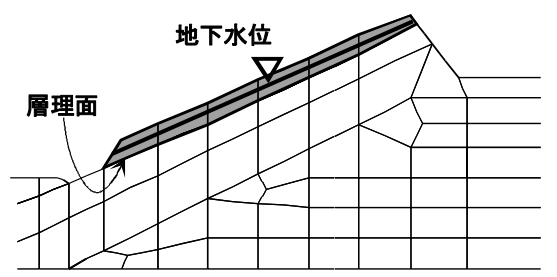

図一14 仮定したすべり土塊内の地下水位

Fig. 14 Assumed groundwater level in sliding body

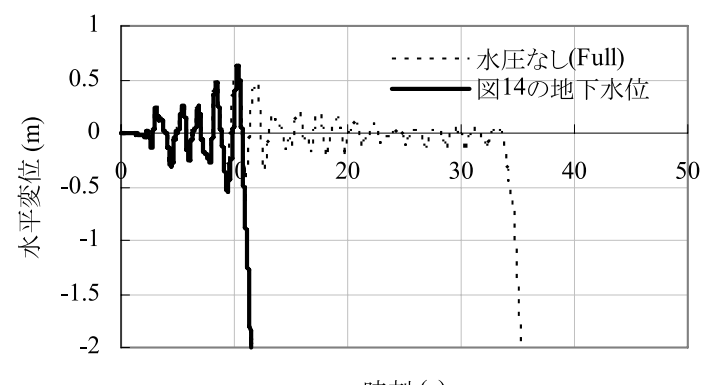

時刻 (s)

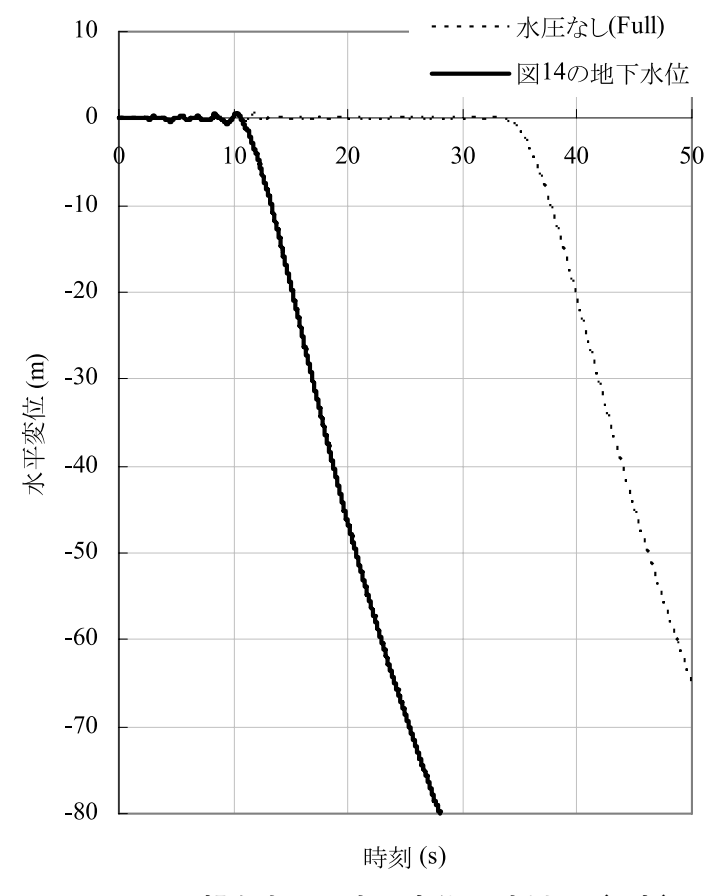

図-15 上部白岩層の水平変位の時刻歴（A点）

Fig. 15 Time history of horizontal displacement of upper Shiroiwa layer (at Point A)

-14のような地下水位が存在していたかどうかは不明で ある。繰返しになるが，地下水位以外にも，地震外力の 評価，材料特性の把握，幾何学形状の単純化など，多く の不確定要因が複合的に現象に関与していることに留意 されたい。

\section{5. まとめ}

本研究で得られた知見のうち，主なものをまとめる。

(1) 2004年の新潟県中越地震で発生した小千谷市横渡地 区の流れ盤斜面の崩壊事例を，二次元動的弾塑性有 限要素法により再現した。繰返し載荷による土のひ ずみ軟化を考虑できる新たな弾塑性構成モデル 


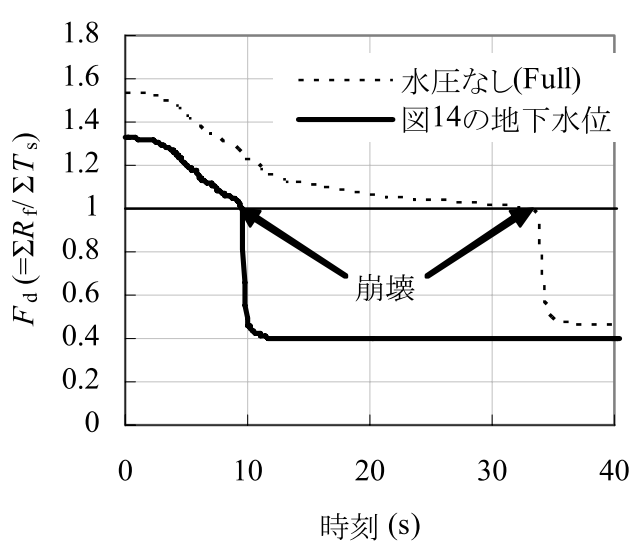

図一16 提案する安定性指標 $F_{d}$ の時刻歴 Fig. 16 Time histories of the proposed index $F_{d}$

（UW軟化モデル）を採用することで，地震時の斜 面崩壊現象を精度良く再現することができた。

(2) すべり面の力学特性の解明は重要である。現場採取 した層理面のブロック採取不摚乱試料の室内試験に より，非排水条件下の繰返しせん断に起因するひず み軟化現象の可能性を確認することができる。

（3）地震時の斜面被害を考える際，斜面の残留変位が限 られた大きさで収束する場合 (変状)，大きく移動 するまで停止しなかった場合（崩壊），の二つを区 別して扱うべきである。後者の発生には, すべり面 のひずみ軟化挙動が大いに関係している。

（4）一時的な超過地震力によりすべり面が塑性化したと しても，すべり面のせん断抵抗力の合計值が上部土 塊の自重に起因する滑動力を下回らなければ，地震 動の終息とともに土塊の運動は停止する。

（5）すべり面のひずみ軟化を考慮する場合，「すべり土 塊の自重に起因するすべり面上の滑動力 $\sum T_{s} 」 に$ 対する「すべり面上で発揮されうる最大のせん断抵 抗力 $\left.\sum R_{f}\right\rfloor$ の比を安定性指標 $F_{d}$ とし，これが1.0を 下回った時に地震時斜面崩壊が発生すると考えれば よい。この崩壊は，(3)で述べた崩壊を表すものであ る。

（6）すべり面上の応力分布を調べた今回の結果によると， 地震前には特に斜面の谷側寄りの部分に偏重して大 きなせん断応力が発生しており, 地震動の入力によ りその谷側末端部付近から徐々に塑性化が進展する。 塑性領域は順次山側へ拡大していき，次第にすべり 面全域のせん断強度低下が顕著になる。

（7）地下水位を考慮した同様の解析により，地下水排除 工の地震時安定に対する有効性などが評価できる。

(8) 高速かつ長距離移動を伴う斜面崩壊を厳密に再現す るには，運動学的な考察が欠かせない。

\section{謝辞}

本研究を進めるにあたり，先端技術を活用した農林水 産研究高度化事業「ため池等の低コスト改修・高度防災
情報による防災対策技術の開発」として多大なるご支援 を頂きました。記して謝意を表します。

\section{引用文献}

浅野志穂, 落合博貴, 黒川潮, 岡田康彦（2006）：山地に扔ける地 震動の地形効果と斜面崩壊への影響, 日本地すべり学会誌, Vol. 42, No. 6, pp. $457-466$.

Griffiths, D. V. and Prevost, J. N. (1988): Two-and threedimensional dynamic finite element analyses of the Long Valley Dam, Geotechnique, Vol. 38, No. 3, pp. 367-388.

Iai, S., Ichii, K., Sato, Y. and Kuwajima, R. (1999) : Earthquake response analysis of a high embankment on an existing hill slope, 2 nd International Conference on Earthquake Geotechnical Engineering, pp. 697-702, Lisboa, Portugal.

石原研而（1976）：土質動力学の基礎，鹿島出版会，pp.196-202. 地盤工学会編（2003）: 弾塑性有限要素法がわかる, 地盤技術者の ためのFEMシリーズ(2), 地盤工学会, pp. 189-216.

尾上篤生, 樋口邦弘, 若井明彦, 鵜飼恵三 (2005) : 新潟県中越地 震における斜面崩壊と層理の強度, 土と基礎, Vol. 53, No. 12, pp. $95-97$.

Onoue, A., Wakai, A., Ugai, K., Higuchi, K., Fukutake, K., Hotta, H. and Kuroda, S. (2006) : Slope failures at Yokowa-tashi and Nagaoka College of Technology due to the 2004 Niigata-ken Chuetsu Earthquake and their analytical con-siderations, Soils and Foundations, Vol. 46, No. 6, pp. $751-764$.

Toki, K., Miura, F. and Oguni, Y. (1985) : Dynamic slope stability analyses with a non-linear finite element method, Earthquake Engineering and Structural Dynamics, Vol. 13, pp. $151-171$.

Ugai, K., Wakai, A. and Ida, H. (1996) : Static and dynamic analyses of slopes by the 3-D elasto-plastic FEM, Proc. of 7th International Symposium on Landslides, pp. 1413-1416, Trondheim, Norway.

渦岡良介（2000）：地盤の液状化発生から流動までを予測対象とす る解析手法に関する研究, 岐阜大学学位論文, pp. 161-170.

Woodward, P.K. and Griffiths, D.V. (1994) : Non-linear dynamic analysis of the Long Valley Dam, Computer Methods and Advances in Geomechanics, Balkema, pp. 1005-1010.

若井明彦, 鵜飼恵三（2003）：液状化による被害程度の簡易予測法 に関する提案，応用力学論文集，Vol.6, pp. 713-721.

Wakai, A. and Ugai, K. (2004) : A simple constitutive model for the seismic analysis of slopes and its applications, Soils and Foundations, Vol. 44, No. 4, pp. 83-97.

若井明彦, 鵜飼恵三, 谷茂 (2005a) : 不均質な土構造物の地震時 残留沈下量に関する信頼性設計のための基礎的研究，応用力 学論文集, Vol. 8, pp. 663-672.

若井明彦，釜井俊孝，鵜飼恵三 $(2005 b)$ : 高町団地に扔ける盛土 崩壊事例の有限要素シミュレーション, 宅地地盤の安全性と 性能評価に関するシンポジウム論文集，地盤工学会，pp. 25 -30 .

若井明彦, 川端宏和, 渡邊泰介, 張 馳, 神藤健一, 田中頼博 (2006 a）：高度な計算環境を前提としない山間地広域FEM震度予測 システム, 第45回日本地すべり学会研究発表会講演集, pp. $297-300$.

若井明彦，天野正道，飯塚豊，鵜飼恵三 (2006b) : ジオグリッド とコンクリートパネルからなる補強土擁壁の耐震性評価のた めの数值解析, 土木学会論文集, No. 813/ III -74, pp. $157-$ 168.

若井明彦, 清水直道, 田村昌仁, 林宏一 (2006c) : 緩傾斜宅地の 地震時残留沈下に関する解析的考察，第 3 回地盤工学会関東 支部研究発表会 (Geo-Kanto 2006) 講演集, pp. 61-66.

吉松弘行, 樫山和男 (2006)：CIVA一安定化有限要素法による地 すべりを起因とする造波解析，日本地すべり学会誌，Vol. 43， No. 3, pp. 131-141.

（原稿受付 2007 年 4 月 3 日，原稿受理2007年 6 月11日） 